\title{
Türkiye Üzerindeki Önemli Kurak Yıllar
}

\author{
Important drought years over Turkey
}

\author{
Abdullah AKBAŞ* \\ Ardahan Üniversitesi, Insani Bilimler ve Edebiyat Fakültesi, Coğrafya Bölümü, Ardahan
}

$\ddot{O}_{z:}$ Bu çalışmanın amacı, literatürde belirlenen yılların kuraklık desenlerinin dă̆ılımının Palmer kuraklık şiddeti indisi (PDSI) kullanılarak elde edilmesi ve bu yaklaşımın kuraklı̆̆g ne kadar temsil ettiğinin belirlenmesidir. Palmer kuraklı şiddeti indisi, Türkiye'de bulunan 96 meteoroloji istasyonunun 1929-2009 yılları arası sıcaklık ve yağış verileri ile ABD'deki ORNL DAAC'nin faydalı su içeriği verileri (available water holding capacities -AWHC) kullanılarak hesaplanmıştır ve daha sonra ise indisin kuraklık sınıfları NOAA'nın kuraklık sınıflarına göre yedi sınıfa ayrılmıştır. Çalışmanın sonuçlarına göre elde edilen kurak yılların sonuçları ile literatürdeki kurak yılların benzerlik sergilediği görülmüşür. Bu bağlamda, Türkiye’de kuraklığın izlenmesinde ve etki azaltmada Palmer kuraklık şiddeti indisi faydalı bir araç olarak önerilmiştir.

Anahtar Kelimeler: Palmer Kuraklık Şiddeti Indisi(PDSI), AWCH, Kurak yıllar, Türkiye

\begin{abstract}
Aim of this study is obtain drought years patterns in literature via Palmer drought severity index (PDSI) and detect performance of this approach. Palmer Drought Severity Index (PDSI) calculated by using the temperature and precipitation data from 96 meteorological stations in Turkey and the data soil water-holding capacity (AWHC) of DAAC in the U.S. ORNL data and then PDSI classes separated to seven drought subclasses as NOAA classification. According to result of this study, obtained drought years and drought years in literature are similar. In this context, Palmer drought severity index is useful tolls in drought mitigation and drought monitoring in Turkey.
\end{abstract}

Key Words: Palmer Drought Severity Index (PDSI), AWCH, Drought years, Turkey

\footnotetext{
* İletişim yazarı: abdullahakbas@ ardahan.edu.tr
} 


\section{Giriş}

Hava ve iklim süreçleri yaşamsal etkilere sahiptirler. Dolayısıyla, iklim sisteminde olabilecek değişiklik ve/veya değişkenlikler doğrudan ona bağlı alt sistemlerinde, bazen gecikmeli de olsa yanıtını bulur. Bu yanıtlardan biri de meteorolojik kuraklıktır. Tüm kuraklıklar ilk önce meteorolojik olarak, yani yetersiz yağışla başlar. Bu durumu toprak neminin azalması ve bitkinin ihtiyaç duyduğu minimum su kapasitesinin azalmasıla tarımsal kuraklık takip eder. Daha sonra ise akarsulardaki ve barajlardaki suların azalmasıyla hidrolojik kuraklık baş gösterir ve bu durum en sonunda kendini sosyo-ekonomik kuraklık olarak gösterir. Su temininde hava durumu (kuraklık) ile ilişkili bir eksiklik sonucu olarak ekonomik bir mal için talebin arzı aşması sonucunda sosyoekonomik kuraklık gerçekleşir. Örneğin Türkiye'de 2007 ve 2008 yılları arası yağışların ortalamanın altında gerçekleşmesi ile önce başlayan meteorolojik kuraklık daha sonra sosyo-ekonomk kuraklığa dönüşerek büyük şehirlerde su kesintisine sebep oldu ve uzun süre su sıkıntısı yaşandı (Şekil 1 ve Şekil 10).

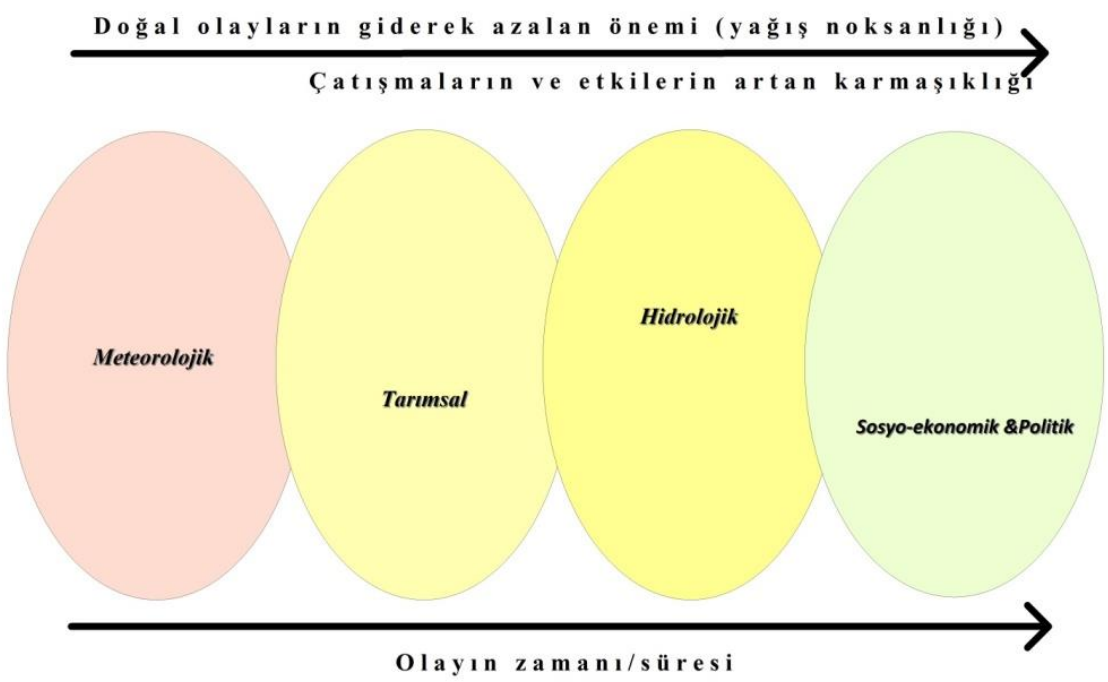

Şekil 1: Kuraklığın etkileri ve sıralaması (Wilhite ve Buchanan Smith, 2005 ile National Drought Mitigation Center, University of Nebraska, Lincoln, Nebraska, USA'dan yararlanarak yeniden çizildi).

Kuraklık başlı başına bir afet olmasına rağmen birkaç bakımdan diğer doğal afetlerden ayrılır: Birinci olarak, kuraklık yavaş başlayan bir afettir. Bundan dolayı, etkileri uzun bir zaman periyodu boyunca birikerek (kümülatif) daha sonraki asıl olumsuz etkileriyle birlikte hissedilir. İkinci olarak, kuraklık kesin ve herkes tarafından kabul edilmiş bir tanıma sahip olmadığı için şiddeti ve var-olup olmadığı kesinliği konusunda kafa karışıklığına yol açar. Üçüncü olarak, kuraklığın etkileri yapısal değildir; yani yıkıcı sel, tropikal firtınalar ve depremler gibi doğal afetlerden daha yaygın bir coğrafi dağılıma sahiptir. Bu da onun etkisini ölçmeyi zor kılar ve diğer doğal afetlerden farklı olarak afet yönetimini zor k1labilir. Ancak kuraklık sosyal (toplumsal) bağlamından ayrık veya kopuk olmamalıdır. Bugün meydana gelen bir kuraklık olayı, geçmiş tarihte meydana gelen bir kuralığın yoğunluğuna ve süresine benzeyebilir; ama toplumsal özelliklerdeki değişimlerden (ekonomik ve teknolojik değişimler) dolayı etkileri büyük bir olasılıkla belirgin farklılıklar gösterecektir (Wilhite, 1996, 2007, Wilhite ve Buchanan-Smith,2005). 
Kuraklık ile ilgili çalışmaları dört başlık içinde sınıflandırılabiliriz. Birinci başlık, kuraklığın oluşumu ve bu oluşuma sebep olan büyük atmosferik dolaşımı (sirkülâsyonu) ile ilgili çalışmaları kapsar. İkinci başlık, çeşitli büyüklüklerdeki kuraklıkların meydana gelme olasılığını karakterize eden kuraklığın oluşum sıklığı (frekansı) ve şiddetini içeren çalışmaları içerir. Üçüncü başlık, kuraklığın etkilerini anlamaya ve tanımlamaya çalışan teorik ve pratiğin birlikte yürütüldüğü çalışmaları kapsar. $\mathrm{Bu}$ başlık kuraklıkla ilişkili zarar kayıpları ve maliyetin üzerinde de odaklanır ki bu kayıplar ekonomik, sosyal ve çevresel olarak da sinıflandırılabilir. Son başlık ise tepkileri ve doğrudan zararı azaltma ile hazırlık stratejileri ile ilgili çalışmaları içerir. Bu safhada, kuraklıkla ilgili etkilerin azaltılması üzerinde odaklanılır (Byun ve Wilhite; 1999).

Kuraklık indisleri, iklimsel değişkenler ve iklim ile ilişkili süreçler (örn. toprak nemi ya da su içeriği) arasındaki karmaşık etkileşimleri özetleyerek görece daha kolay anlaşılmasını sağladığı için, kuraklığın ölçülmesi ve izlenmesi için yararlı yöntem ve yaklaşımlar olarak kabul edilir. Kuraklık indislerinin kullanılması, iklimsel anomalilerin şiddet, coğrafi yayılış ve oluşum sıklığı açısından niceliksel olarak değerlendirilmesine izin vermesinin yanı sıra, hem karar vericiler hem de toplum ve yurttaşlar arasında kuraklık koşulları konusunda bilgi değişimini sağlar(Türkeş ve Tatlı,2010; Türkeş, 2010)

Bu çalışmada, literatürde belirlenen yılların klimatolojik açıdan, kuraklık desenlerinin Palmer indisleri kullanılarak elde edilmesi ile bu yaklaşımın kuraklığı ne kadar temsil ettiğinin belirlenmesi amaçlanmıştır.

\section{Veri ve yöntem}

Bu çalışmada kullanılan gözlem verileri, Meteoroloji Genel Müdürlüğü’nün (MGM) 96 adet klimatoloji ve meteoroloji istasyonunun verileri kullanılarak Türkeş $(1996,1998)$ ve Türkeş vd. (2002) ile Türkeş ve Sümer (2004) tarafından hazırlanmış olan sırasıyla Türkiye yağış ve hava sıcaklığı veri setlerinin 2009 yılına kadar güncelleştirilen, 1929-2009 dönemi aylık toplam yağış ve aylık ortalama sıcaklık zaman dizileridir (Şekil 2). Faydalı Su İçeriği (available water holding capacities-AWCH) verileri ise Amerika Bileşik Devletleri'nde bulunan Oak Ridge National Laboratory Distributed Active Archive Centre (ORNL DAAC) 1-m toprak derinliği veri kümesinden elde edildi (Webb vd., 2000). AWCH değerleri $0.5-0.5^{\circ}$ gridli olduklarından, gridli noktalardaki veriler söz konusu meteoroloji istasyonlarına en yakın komşu interpolasyon yöntemi ile taşınarak işlemler yapıldı.

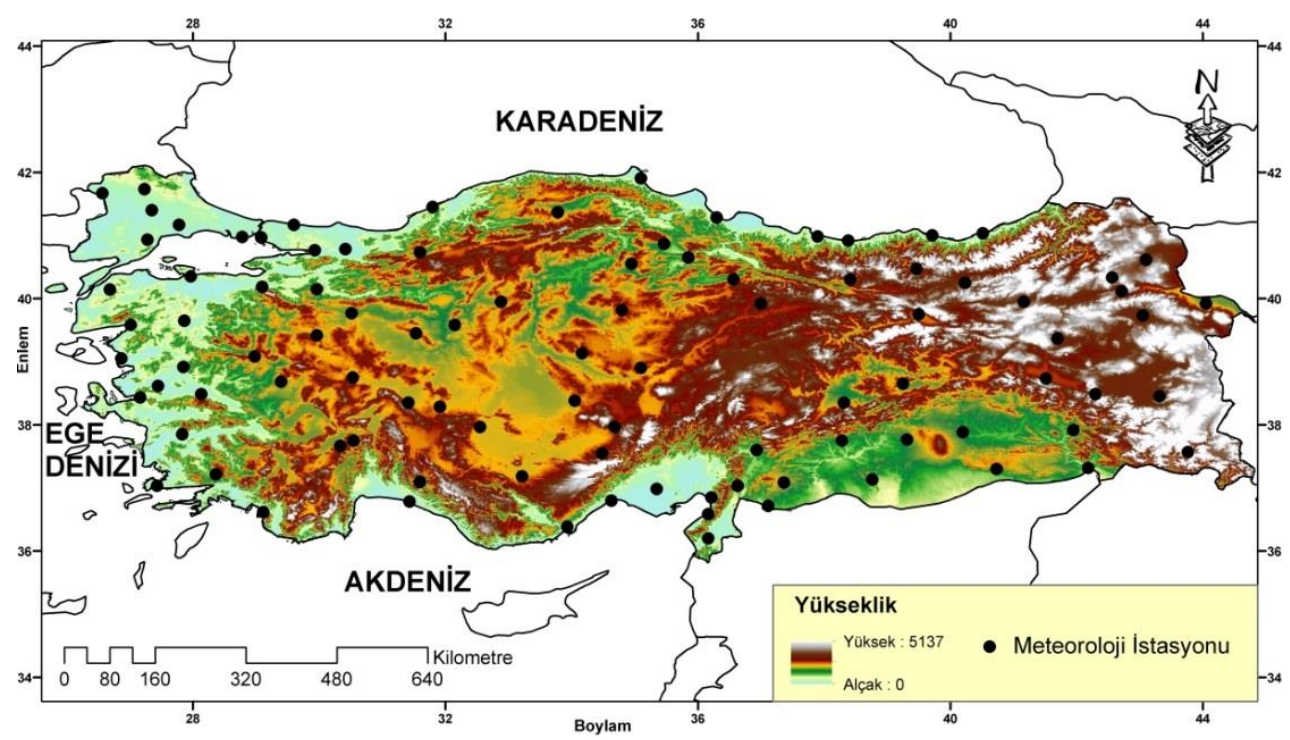

Şekil 2: PDSI hesaplamalarında kullanılan istasyonların coğrafi dağılımı 
Palmer Kuraklık İndeksi, Palmer (1965) tarafindan geliştiren, aylık veya haftalık olarak hesaplanabilen bir indistir. $\mathrm{Bu}$ indisin hesabında ortalama sıcaklık, toplam yağış, faydalı (kullanılabilir) su içeriği (AWHC) ve potansiyel evapotranspirasyon (terleme-buharlaşma) gözlemleri kullanılır ve indis basit bir sayıdan oluşur. Meteorolojik kuraklığın izlenmesinde kullanıldığından, meteorolojik kuraklık indisi olarak da adlandırılır. $\mathrm{Bu}$ indisin belirlenmesinde, potansiyel evapotranspirasyon miktarları ise Thornthwaite yöntemi ile hesaplanır. Bu indisin hesaplamasındaki kabul ve sınırlamaları Alley (1984) yeniden gözden geçirmiştir.

Palmer Kuraklık Şiddet İndisinin hesaplanması ve temel eşitlikleri, Alley (1984) ve Tatlı ve Türkeş (2011)'den yararlanılarak verilmiştir. Palmer Kuraklık Şiddet İndisi'nin hesaplanmasında toprak nemi, üst bölüm veya yüzey nemi $(\mathrm{Ss})$ ve alt bölüm nemi $(\mathrm{Su})$ olmak üzere ikiye ayrilarak hesaplamalara başlanır. Bu adımda, tüm toprak neminin $25 \mathrm{~mm}$ kısmının toprağın üst bölümünde yer aldığ 1 kabulü vardır. Dolayısıyla, AWHC değeri, yüzey tabakada $25 \mathrm{~mm}$ olmak üzere, bu iki toprak tabakası arasında paylaştırılır.

Toprak üstünden olan buharlaşma ve terlemeyle olan su kaybı, potansiyel buharlaşma-terleme (PET) olarak tanımlanır. Eğer PET değeri toplam yağıştan büyük ise, bu durumda PET > P olduğundan,

$$
\begin{aligned}
& L_{s}=\min \left[S_{s},(P E T-P)\right] \\
& L_{u}=\left[(P E T-P)-L_{s}\right] S_{u} / A W H C, L_{u} \leq S_{u}
\end{aligned}
$$

olmak üzere 2 ara değişken hesaplanır. Burada $P$ yağışı, $S_{s}$ ve $S u$ sırasıyla toprağın üst ve alt tabakasında depolanan nem miktarlarını temsil etmektedir. Buharlaşma-terleme (ET) ile kayıp ve yeniden dolum (recharge) yüzey tabaka içinde yer aldığı kabul edilir. Dolayısıyla, bu yüzey tabakadaki maksimum nem kaybının en fazla $P E T^{6}$ e eşit olacağı anlamına gelir. Diğer taraftan, toprağın alt tabakasından olan nem kaybı miktarı ise başlangıçta toprakta bulunan nem içeriğine, yani başlangıçtaki AWHC miktarına çok sıkı bağlıdır. Yani, toprak-altı tabakasının su şarjı ancak tüm AWHC değerinin kaybolmasından sonra başlamaktadır.

Diğer bir büyüklük olan yüzey akış (runoff) ise bu iki toprak tabakasının nem miktarının tarla kapasitesine ulaşmasından sonra başlayabileceği varsayımına dayanır. Özetle, PDSI hesabında, nemfarkı (moisture departure) indisi olarak adlandırılan $\mathrm{d}_{\mathrm{j}}$ ile hesaplamalara başlanır.

$$
d_{j}=P_{j}-\hat{P}_{j}
$$

Burada $P_{j}, j$-inci ayın toplam yağış tutarını ve $\hat{P}_{j}$ ise $j^{\prime}$ inci ayın klimatolojik koşulların oluşturduğu uygun yağış tutarını (Climatologically Appropriate for Existing Conditions: CAFEC) temsil etmektedir. Bu CAFEC değeri, su dengesi yaklaşımı kullanılarak, her j'inci ay için aşağıdaki denklem ile elde edilir.

$$
P_{j}=\alpha P E T_{j}+\beta P R_{j}+\gamma P R O_{j}-\delta P L_{j}
$$

Yukarıdaki verilen Denklem'de, $P R$ potansiyel toprak nemi şarjını (potential soil moisture recharge), $P R O$ potansiyel akışı (potential runoff) ve PL ise topraktan potansiyel nem kaybını (potential water loss from the soil) temsil etmektedir. Diğer taraftan, yılın her j'inci ayı için $\alpha, \beta, \gamma, \delta$ katsayıları ise aşağıda verilen ifadeler ile elde edilir. 


$$
\begin{aligned}
& \alpha_{j}=\frac{\overline{E T}_{j}}{P E T_{j}} ; \text { ĕger } \overline{P E T_{J}}>0, \text { aksi } \alpha_{j}=1 \\
& \beta_{j}=\frac{\bar{P}_{j}}{P R_{j}} ; \text { ĕger } \overline{P R_{J}}>0, \text { aksi } \beta_{j}=1 \\
& \gamma_{j}=\frac{\overline{R O}_{j}}{P R O_{j}} ; \text { ĕger } \overline{P R O_{J}}>0, \text { aksi } \gamma_{j}=1 \\
& \delta_{j}=\frac{\bar{L}_{j}}{P L_{j}} ; \text { ĕger } \overline{P L_{J}}>0, \text { aksi } \delta_{j}=1
\end{aligned}
$$

Yukarıdaki ifadelerde, üzeri çizgili olan terim ilgili değişkenin uzun-süreli ortalamasını temsil etmektedir. PET miktarı ise Thornthwaite (1948) yaklaşımı ile elde edilir. Şöyle ki:

$$
P E T=d l \cdot 1.6 \cdot\left(\frac{10 T_{j}}{I}\right)^{b}
$$

Burada PET'in birimi $\mathrm{cm}$ ve $d l$ ise ilgili yerin enlem-derecesinden hesaplanan gün uzunluğu düzeltme faktörüdür $(d l=1$ için gün uzunluğu 12 saat anlamına gelir). Aynı denklemde, $T$ aylık ortalama sicaklık (birimi ${ }^{\circ} \mathrm{C}$ ) ve $I$ ise 1 s1 indeksi (heat index) ve 12 ayın 1 si indekslerinin toplamı olarak aşağıdaki ifade ile elde edilir.

$$
I=\sum_{j=1}^{12}\left(\frac{T_{j}}{5}\right)^{1.514}
$$

Denklem (4)`deki $b$ sabiti ise ampirik olarak 1sı indeksinden elde edilir:

$$
b=6.75 \cdot 10^{7} \cdot I^{3}-7.71 \cdot 10^{5} \cdot I^{2}+1.79 \cdot 10^{2} \cdot I+0.49
$$

Potansiyel yeniden dolum, $P R$, toprağın yeniden tarla-kapasitesine gelmesi için gerekli su miktarı olarak tanımlanır ve aşağıdaki ifade kullanılarak, toprak tabakalarında bulunan nem miktarı ve AWHC değerleri kullanılarak hesaplanır.

$$
P R=A W C H-\left(S_{s}+S_{u}\right)
$$

Potansiyel yağış (PRO) ise potansiyel yağıştan, potansiyel yeniden dolumun (PR) çıkartılması ile elde edilen bir büyüklüktür. 


$$
P R O=A W C H-P R=\left(S_{s}+S_{u}\right)
$$

Topraktan olan potansiyel nem kaybı (PL) yağış döneminin sıfir olduğu durumda, buharlaşmaterleme için topraktan olan su miktarı kaybı olarak tanımlanır.

$$
P L=P L_{s}+P L_{u}
$$

Bu denklemdeki $P L_{s}$ ve $P L_{u}$ terimleri aşă̆ıdaki gibi tanımlanırlar.

$$
P L_{S}=\min \left(P E T, S_{S}\right)
$$

$$
P L_{u}=\left(P E T-P L_{s}\right) S_{u} / A W C H, P L_{u} \leq S_{u}
$$

Yukarıda Denklem (4) ile tanımlanan $\alpha, \beta, \gamma$ ve $\delta$ katsayıları yılın her 12 ayı için veya 52 hafta için) belirlendikten sonra, Palmer Nem Anomali İndeksi (Z-İndeksi), nem sapmasından, yani $d_{j}{ }^{\prime}$ den her $j$ 'inci ay için hesaplanır.

$$
Z_{j}=d_{j} \cdot K_{j}
$$

Buradaki $K_{j}$ ampirik bir katsayı olan ve j'inci ayın ağırlık faktörü olarak tanımlanır. Bu katsayı başlangıçta, bölgesel iklim düzeltme katsayı olarak adlandırılan ve ampirik olarak bulunan, $K_{i}$ lerden hesaplanır. şöyle ki:

$$
K_{j}=\left(\frac{17.67}{\sum_{i}^{12} \bar{D}_{i} \grave{K}_{i}}\right) \grave{K}_{j}
$$

Bu ifadede kullanılan $\grave{K}_{j}$, ise aşağıda gibi deneysel olarak bulunur.

$$
\grave{K}_{j}=1.5 \cdot \log \left(\frac{\frac{\overline{P E T}_{j}+\bar{R}_{j}+\overline{R O}_{j}}{\bar{P}_{j}+\bar{L}_{j}}+2.8}{D_{j}}\right)+0.5
$$

$D_{j}$ kalibrasyon veya normal değerlerin hesaplandığı periyot boyunca elde edilen, nem sapma değerleri olan dj‘lerin aritmetik ortalamasıdır

Tüm yukarıda tanımlanan katsayılar ve değişkenler belirlendikten sonra, PDSI değerleri her $j$ inci ay için aşağıda verilen denklemle ardışık olarak elde edilir.

$$
X_{j}=\frac{1}{3} Z_{j}+0.897 X_{j-1}, X_{-1}=0
$$


Bu denklemde, $X$ sembolü PDSI'i temsil etmektedir. Hesaplan PDSI değerleri, Palmer (1965) tarafından önerilen kuraklık sınıflarına dönüştürülür (Çizelge 1). Bu çalışmada kuraklıklar yorumlama açısından kolaylık sağlaması için NOAA'nın sınıflarına dönüştürüldü (Aşırı nemli ( $\geq$ ve 4 ), çok nemli (3 ve 3.99), orta nemli (2 ve 2.99), normal (1.99 ve 1.99), orta kurak (-2 ve -2.99$)$, şiddetli kurak (-3 ve -3.99), aşırı kurak ( $\leq$ ve -4$)$ ).

Bu çalışmanın konusu olan ve tespit edilen kurak yıllar 1971, 1972, 1973, 1974, 1983, 1984, 1989, 1990, 1991, 1992, 1993, 1994, 2001, 2006, 2007, 2008 y1lları olarak belirlenmiştir (Türkeş,1990; Türkeş, 2011; Türkeş ve Erlat, 2003, 2005; Türkeş vd., 2009). Seçilen bu yılların hem kış dönemi (Şubat) hem yaz dönemi (Temmuz) haritaları çizilerek, Türkiye ölçeğindeki desenleri elde edilmiştir.

Çizelge 1: Palmer Kuraklık Şiddeti İndisi ve Sınıflaması

\begin{tabular}{cc} 
PDSI & Kuraklık Sinıfi \\
\hline$\geq 4$ & Aşırı nemli \\
3 ve 3.99 & Çok nemli \\
2 ve 2.99 & Orta nemli \\
1 ve 1.99 & Hafif nemli \\
0.5 ve 0.99 & Yeni başlayan nemli dönem \\
0.49 ve -0.40 & Normal \\
-0.5 ve -0.99 & Yeni başlayan kurak dönem \\
-1 ve -1.99 & Hafif kurak \\
-2 ve -2.99 & Orta kurak \\
-3 ve -3.99 & Şiddetli kurak \\
$\leq-4$ & Aşırı kurak \\
\hline
\end{tabular}

\section{Bulgular}

\subsection{1 ve 1972 yılı kuraklık desenleri}

Türkiye'de yağış klimatolojisi açısından yağışlı ve nemli bir ay sayılan şubat ayında 1971 Şubat Palmer Kuraklık Şiddeti İndisi haritasına bakıldığında Doğu Anadolu Bölgesi, Güney Doğu Anadolu bölgesi ile Orta-Doğu Karadeniz, İç Anadolu'nun Yukarı Kızılırmak, Konya ve Yukarı Sakarya bölümünün bir kısmı dışında Türkiye'nin neredeyse yarısında kurak koşullar görülmüştür. Nemli koşullar ise görülmemiştir (Şekil 3a). Yağış klimatolojisi açısından sıcak ve kurak bir ay sayılan temmuz ayında Palmer Kuraklık Şiddeti İndisinin 1971 Temmuz ayı haritasına genel bir şekilde bakıldığında ise kurak alanlar şubat ayına göre daralmış nemli alanlar ise daha da genişlemiştir. Doğu ve Güneydoğu Anadolu dışında hemen her yerde normal ve nemli alanların varlığı gözlemlenmiştir (Şekil3b).

1972 Şubat ayında İskenderun körfezinden başlayan Akdeniz bölgesinin Adana Bölümü'nü geçerek Yukarı Fırat Bölümünden Doğu Karadeniz'in güneyine doğru bir kuşak halinde uzanan alan boyunca ve Antalya ile Saroz ve Edremit körfezi etrafı haricide hemen her yerde normal alanların varlığı gözlenmiş̧ir (Şekil3c). 1972 yılının temmuz ayında ise kurak bir ay beklenirken Trakya haricinde Türkiye'nin Güneydoğu, Doğu Anadolu ve Batı Karadeniz Bölümü'nde aşırı nemli olmak üzere hemen her yerde normal koşullar ile nemli alanlar gözlenmiştir (Şekil 3d). 
a)

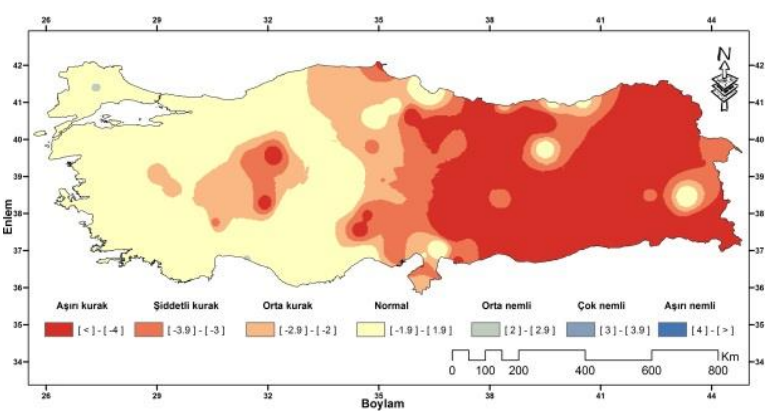

c)

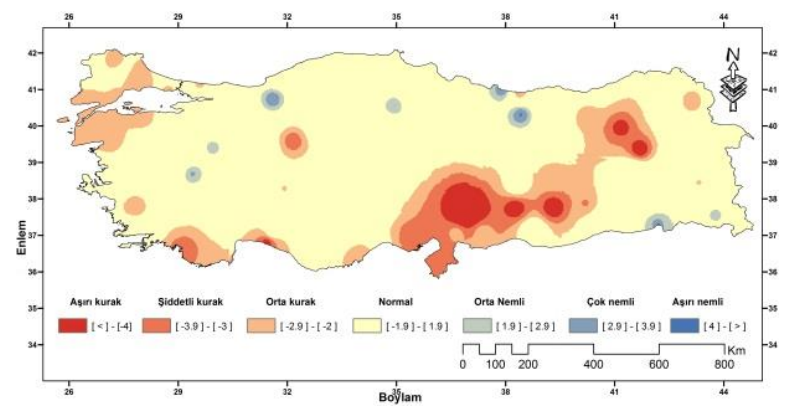

b)

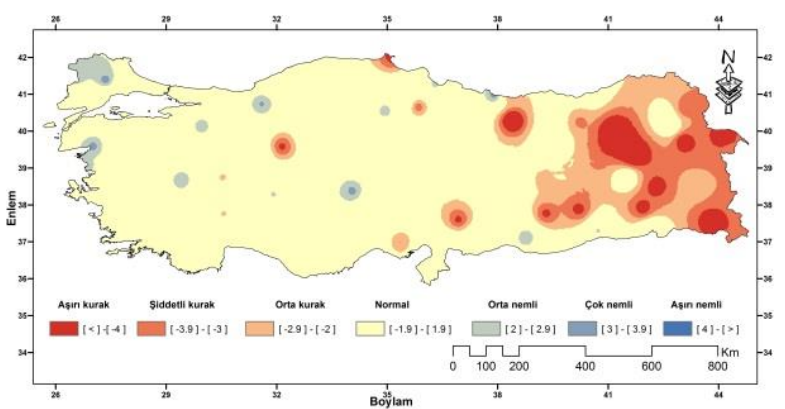

d)

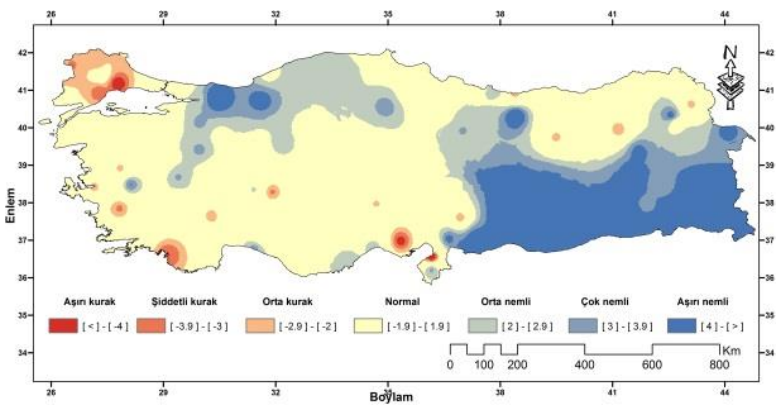

Şekil 3: 1971 ve 1972 yılı şubat ve temmuz ayı Palmer kuraklık şiddeti indisi haritaları: (a) 1971 yılı Şubat ayı PDSI haritası, (b) 1971 yılı Temmuz ayı PDSI Temmuz haritası, (c) 1972 yılı Şubat ayı PDSI haritası, (d) 1972 yılı Temmuz ayı PDSI haritasi.

\subsection{3 ve 1974 y1lı kuraklık desenleri}

1973 yılının Palmer kuraklık şiddeti indisi şubat ayı desenlerine göre Türkiye'de İç Anadolu Bölgesi, Akdeniz Bölgesi, Güneydoğu Anadolu Bölgesi, Doğu Anadolu'nun Yukar1 Fırat Bölümü ile Orta ve Doğu Karadeniz'in batısının haricinde hemen hemen her yerde normal alanların varlığ gözlenmiştir. Nemli alanların varlığı ise çok yerel kalmıştır (Şekil 4a). Temmuz ayından ise şubat ayındaki desenlerin neredeyse aynısı gözlenir ancak şiddeti ise daha fazladır. (Şekil4b).

1974 yılı şubat ayındaki mevcut kurak koşullar Türkiye'nin neredeyse tüm bölgelerinde görülmüştür. Akdeniz Bölgesi, Nevşehir platosu haricinde tüm İç Anadolu, Cudi dağı ile Mardin çevresi haricinde tüm Güneydoğu Anadolu bölgesi, Doğu Anadolu, Orta ve Doğu Karadeniz, Sığacık körfezinden başlayarak tüm Biga ile Kapıdağı Yarımadası, Kula çevresi ve Trakya'nın güneyi haricinde her yerde normal koşullar yaşanmıştır. Bolu Dağları, İzmit körfezi, Mudanya civarı ile Ovacık dağı civarında yerel olarak nemlilik koşulları görülmüştür (Şekil 4c). Temmuz ayındaki kurak koşullar nemli dönem olan şubat ayının desenleri ile benzer olmakla birlikte hem şiddeti hem de alanı biraz daha genişlemiştir (Şekil 4d). 
a)

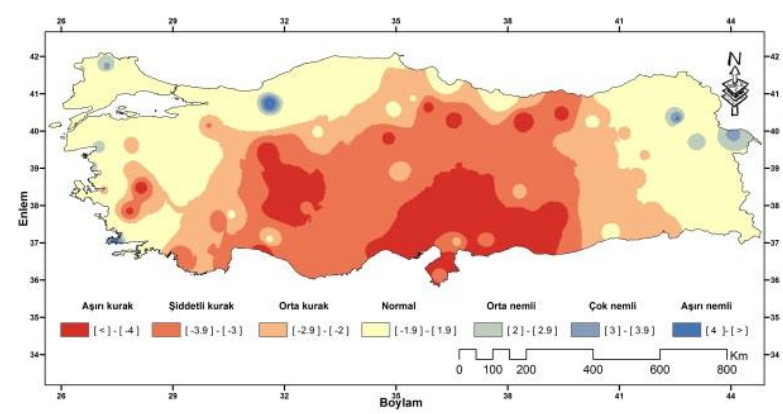

c)

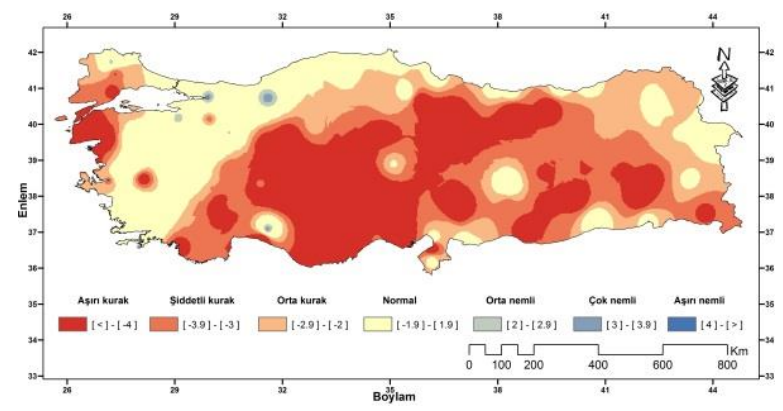

b)

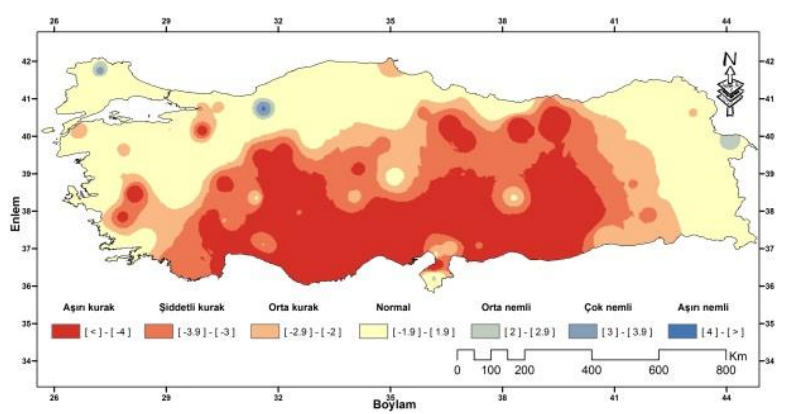

d)

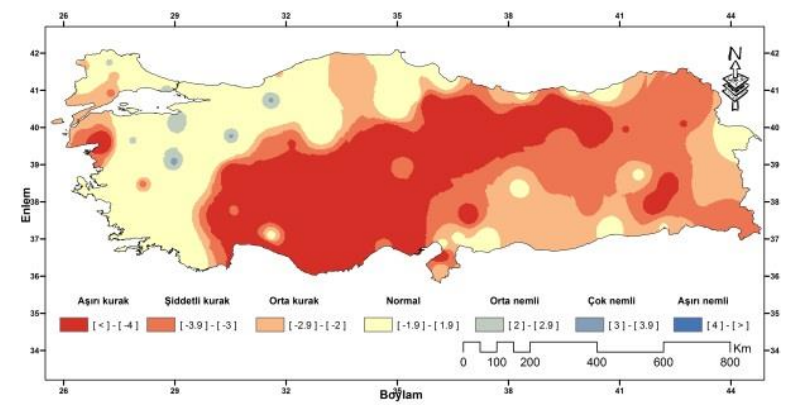

Şekil 4: 1973 ve 1974 yılı şubat ve temmuz ayı Palmer kuraklık şiddeti indisi haritaları: (a) 1973 yılı Şubat ayı PDSI haritası, (b) 1973 yılı Temmuz ayı PDSI Temmuz haritası, (c) 1974 yılı Şubat ayı PDSI haritası, (d) 1974 yılı Temmuz ayı PDSI haritas1.

\subsection{3 ve 1984 y1lı kuraklık desenleri}

1983 y1lı şubat ayında Malatya dağlarından başlayarak Türkiye'nin kuzeydoğusuna doğru şiddetlenen kurak alanlar ile Trakya'nın Lalapaşa yöresinden başlayarak Biga Yarımadasını geçerek Sivrihisar yöresine doğru uzanan kurak alanlar birlikte Sinop, Samsun ve Kahramanmaraş çevreleri haricinde hemen her yerde normal koşullar görülmüştür. Ayrıca aşırı nemli koşullar ise Mardin eşiği, Trabzon, Ordu, Şile civarı, Gökova körfezi ve Aydın Dağları civarında gözlenmiştir (Şekil 5a). Temmuz ayında kurak alanlar daha da daralmakla birlikte nemli ve normal alanların varlığı daha da çoğalmıştır. Türkiye'de Doğu Anadolu'nun Erzurum-Kars Bölümü’nün Kuzeydoğusu ile Bayburt ve Erzincan ovası arasında, Yukarı Sakarya Havzası çevresi, Edremit körfezi çevresi haricinde normal ve nemli alanlar gözlemiştir (Şekil 5b).

1984 y1lının nemli dönemi olan şubat ayında Türkiye'nin Doğu Anadolu Bölgesi'ndeki Cudi dağından başlayıp Şanlıurfa Platosuna oradan da kuzeye doğru Batı Karadeniz'de Hopa'ya doğru bir kuşak halinde uzanan kurak alanları ile Erzurum-Kars platosu ve Trakya'nın kuzey ve güneyin haricinde hemen her yerde normal alanlar gözlenmiştir. Nemli koşullar ise Ege Bölgesi'nin Ege Bölümü ile İç Batı Anadolu'nun batısında, Küre Dağları civarı ile Bozok platosu arası ve İzmit körfezi civarında meydana gelmiştir (Şekil 5c). Temmuz ayında şubat ayına nazaran batıdaki ve kuzeydeki kurak alanlar daralmıştır. Ayrıca güneydoğu ile iç bölgelerdeki kurak alanlar genişlemişle birlikte batıdaki nemli alanlar yok denecek kadar azalmış ve kuzeybatıdaki nemli alanlar genişlemiştir. Türkiye'de Güneydoğu Anadolu Bölgesi, Hakkâri ve Bayburt çevresi ile Tuz Gölü havzası etrafi haricinde hemen her yerde nemli ve normal koşullar hakim olmuştur. Bununla birlikte nemli alanlara bakıldığı zaman Türkiye'de özellikle Batı Karadeniz'in tamamı ile Orta Karadeniz'in batısı, Yukarı 
Sakarya Bölümü'nün kuzeydoğusu, Çatalca-Kocaeli Bölümü'nün batısında, Erzurum-Kars platosu ve Manisa Bozdağlar civarında görülmüştür (Şekil 5d).

a)

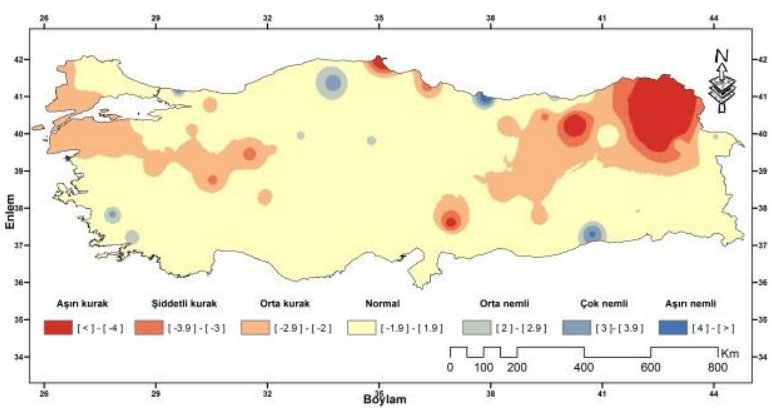

c)

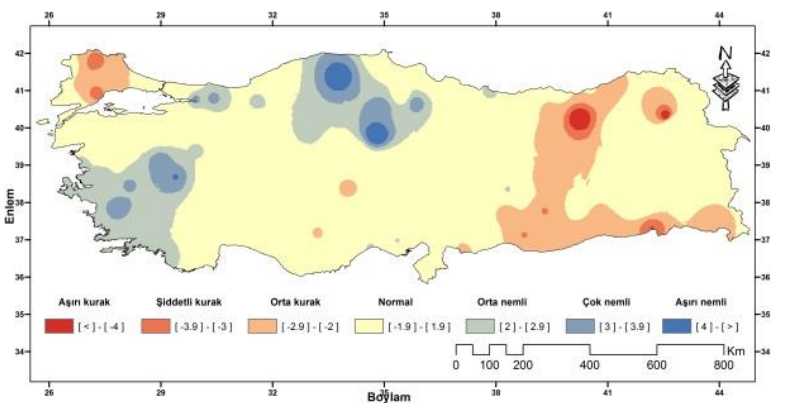

b)

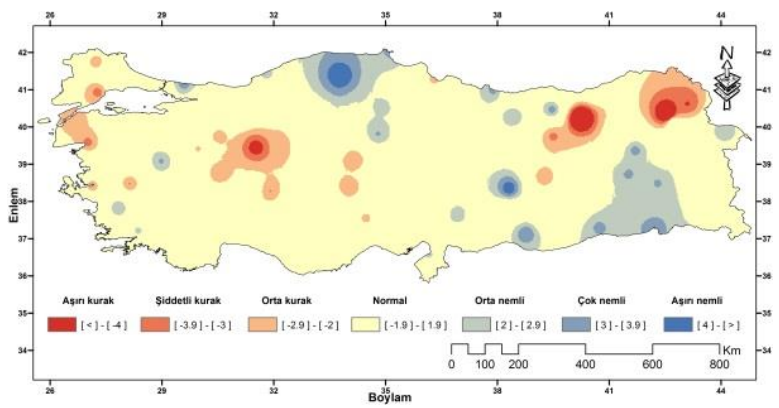

d)

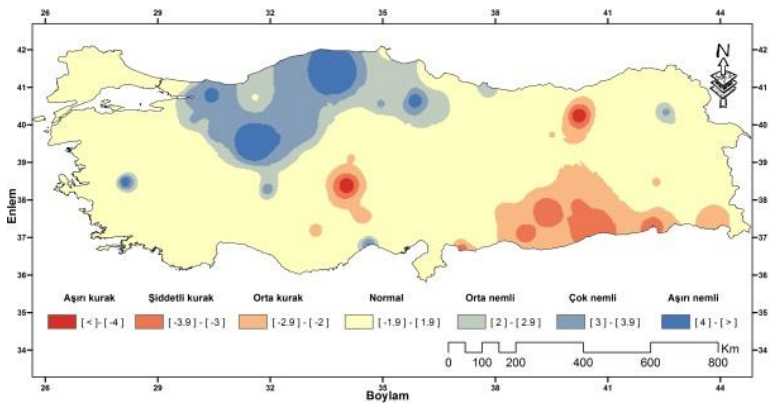

Şekil 5: 1983 ve 1984 yılı şubat ve temmuz ayı Palmer kuraklık şiddeti indisi haritaları: (a) 1983 yılı Şubat ayı PDSI haritası, (b) 1983 yılı Temmuz ayı PDSI Temmuz haritası, (c) 1984 yılı Şubat ayı PDSI haritası, (d) 1984 yılı Temmuz ayı PDSI haritası.

\subsection{9 ve 1990 yılı kuraklık desenleri}

1989 yılının Şubat ayında Türkiye’de Ege Bölgesi, Güneydoğu Anadolu Bölgesi ve Ankara yöresi haricinde hemen her yerinde normal ve nemli bir koşullar yaşanmıştır. Ayrıca aşırı nemlilik durumları ise Orta ve Doğu Karadeniz bölümünde görülmüştür. Bunun dışında Van ve Kars yöresinde de yerel olarak aşırı nemlilik koşulları gözlemlenir (Şekil 6a).1989 yılının Temmuz ayında Orta ve Doğu Karadeniz Bölgesi, İç Anadolu Bölgesi ve Marmara Bölgesinin Trakya ve Edremit körfezi bölümünün çevresi dışında Türkiye'nin hemen her yerinde hem şiddetli hem de aşırı kuraklık koşulları yaşanmıştır. Bunların dışında kuraklığın normal olarak kabul edildiği yerler içerisinde ekstrem nemlilik koşulları gözlenir (Şekil 6b).

Türkiye'de 1990 yılının şubat ayında Marmara, Ege, Batı Akdeniz, Eskişehir ve Mardin illeri dışında hemen her yerde normal ve nemli bir koşullar oluşmuştur. Ekstrem nemli koşullar ise özellikle Orta ve Doğu Karadeniz ile Doğu Anadolu bölgesinin bazı kısımlarında görülür (Şekil 6c).1990 yılının Temmuz ayında nemli dönem olan Şubat ayında farklı olarak kurak olan yerler daha şiddetli ve yaygın olmuştur. Özellikle şubat ayında Mardin ve çevresindeki var olan kuraklık daha genişlemiş ve şiddetlenmiştir. Aynı şekilde batı bölgelerindeki kuraklıklar daha da şiddetlenmiştir. Kışın var olan nemli bölgeler ise iç bölgelere doğru genişlemiş ve normal koşullar daralmıştır (Şekil 6d). 
a)

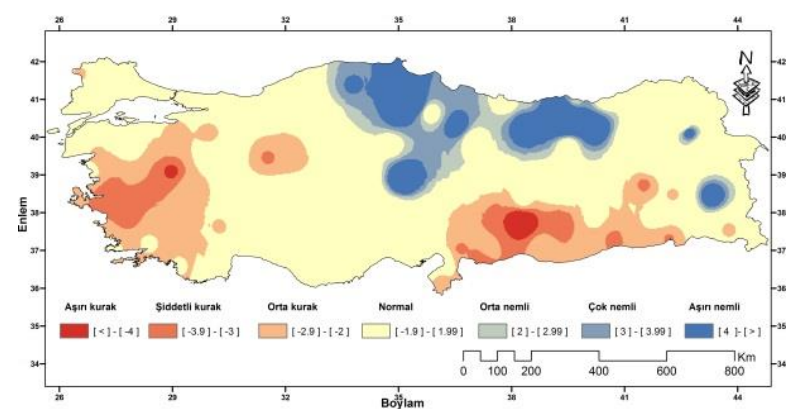

c)

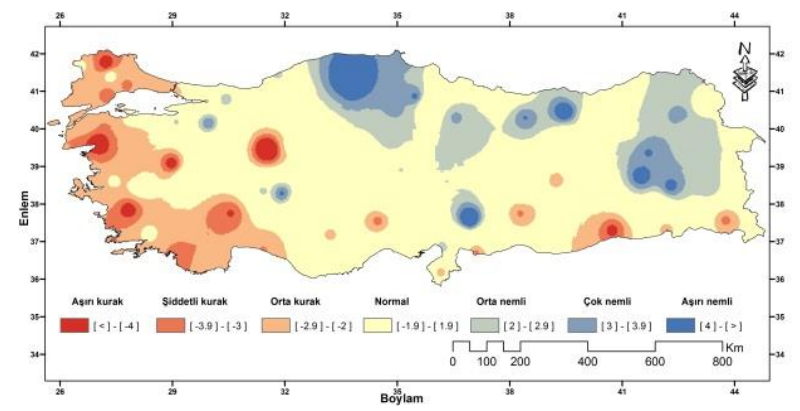

b)

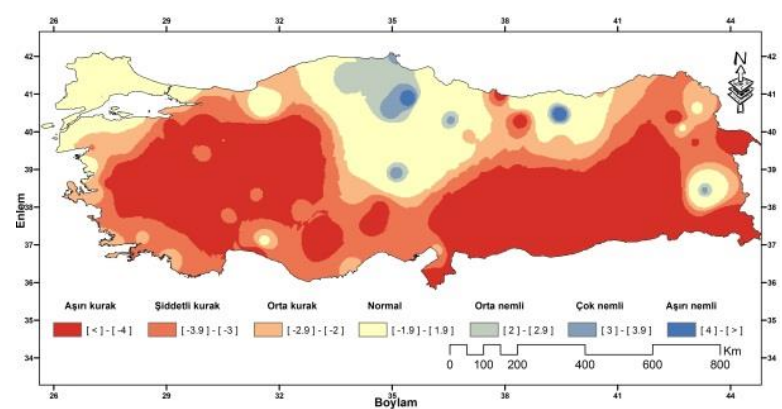

d)

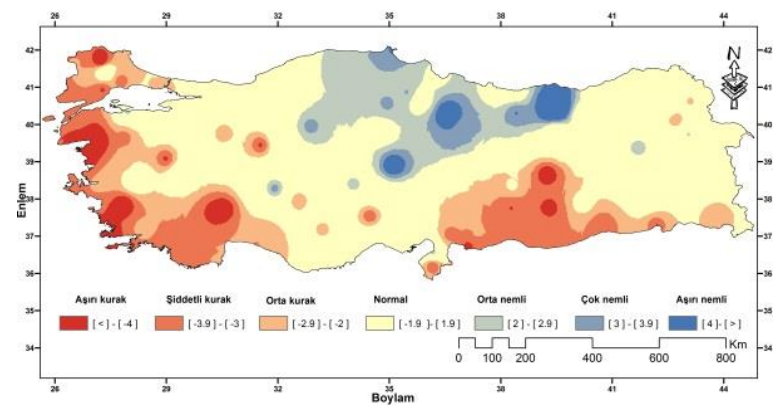

Şekil 6: 1989 ve 1990 yılı şubat ve temmuz ayı Palmer kuraklık şiddeti indisi haritaları: (a) 1989 yılı Şubat ayı PDSI haritası, (b) 1989 yılı Temmuz ayı PDSI Temmuz haritası, (c) 1990 yılı Şubat ayı PDSI haritası, (d) 1990 yılı Temmuz ayı PDSI haritas1.

\subsection{1 ve 1992 yılı kuraklık desenleri}

1991 yılı şubat ayı kuraklık dağılış haritasında kurak alanlar Trakya'dan başlayıp Tüm Ege ve Akdeniz kıyılarına da geçtikten sonra Güneydoğu Anadolu Bölgesi'nde geçip Doğu Anadolu'nun Hakkâri Bölümü’nde son bulur. Ancak aşırı kuraklık özellikle Güneydoğu Anadolu ile Doğu Anadolu Bölgesi'nde daha etkin olmakla birlikte Türkiye'nin geri kalan kısımlarında normal koşullar yaşanmıştır. Ayrıca nemli koşullar ise Zigana ile Otlukbeli Dağları arası, Küre Dağları ve Nevşehir Platosu çevresi çok yerel olarak gözlenmiştir (Şekil 7a).Temmuzda ise şubat ayında yaşanan kuraklıklar giderek azalmış ve klimatolojik olarak kurak olması beklenen bu ayda daha nemli koşullar yaşanmıştır. Taşeli yarımadası, Hakkâri, Mardin ile Şanlıurfa platosu, Elazı̆̆g, Akşehir gölü, Yıldız Dağları, Aydın dağları etrafı haricinden her yerde normal ve nemli koşullar yaşanmıştır. Nemli koşullar Küre Dağlarında olmak üzere Batı Karadeniz'in tümünde, Canik Dağları ile Tahtalı Dağları aras1, Marmara Bölgesi, Ege bölgesi ve Erzurum-Kars platosu, Gümüşhane ile Kaçkar Dağları arasında gözlenmiştir (Şekil 7b). 
a)

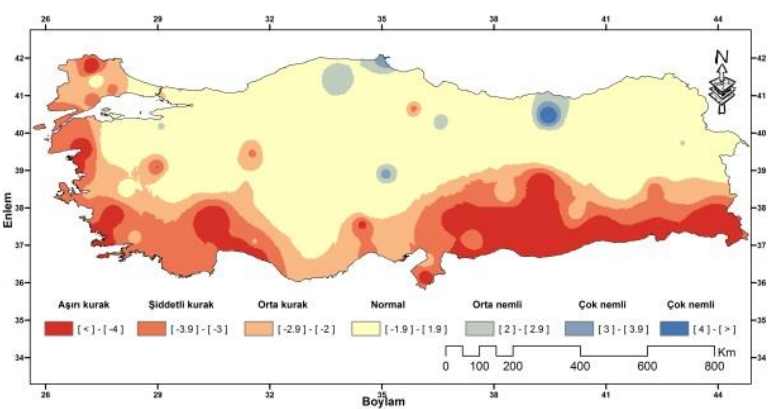

c)

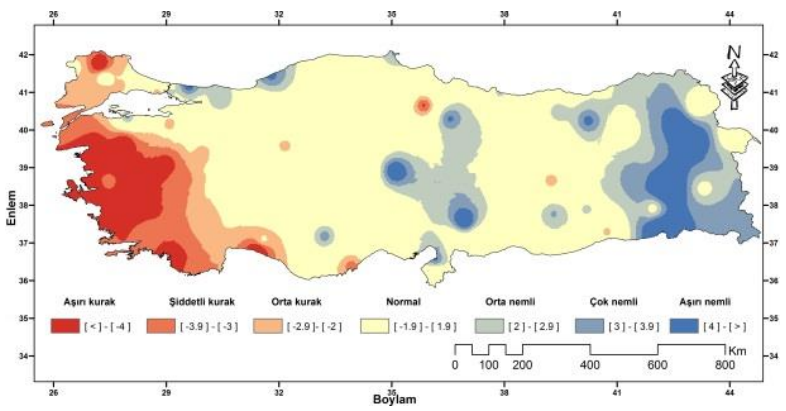

b)

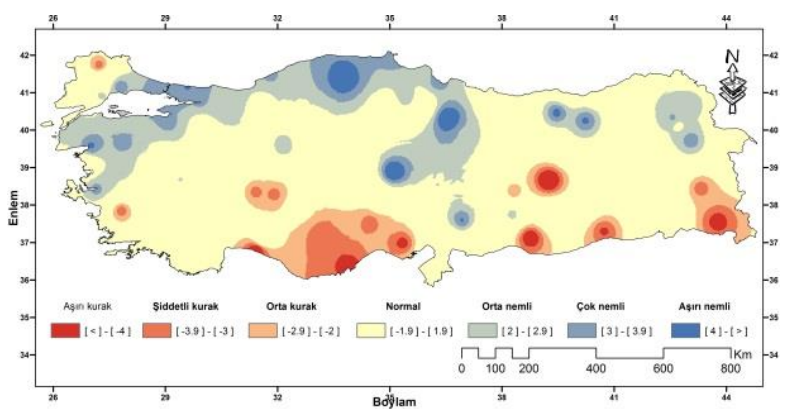

d)

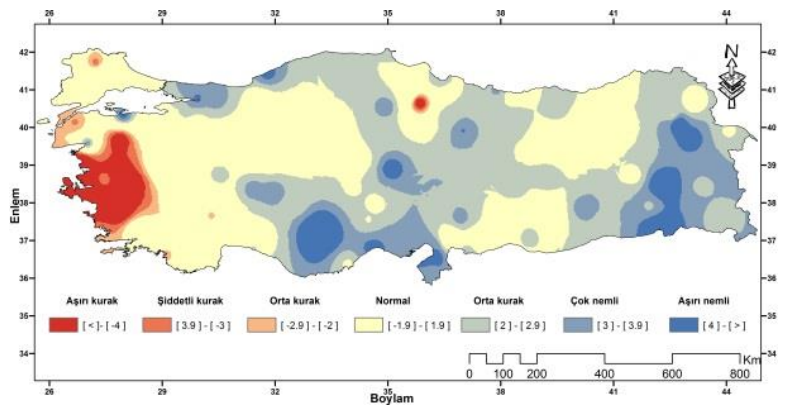

Şekil 7: 1991 ve 1992 yılı şubat ve temmuz ayı Palmer kuraklık şiddeti indisi haritaları: (a) 1991 yılı Şubat ayı PDSI haritası, (b) 1991 yılı Temmuz ayı PDSI Temmuz haritası, (c) 1992 yılı Şubat ayı PDSI haritası, (d) 1992 yılı Temmuz ayı PDSI haritasi.

1992 yılının şubat ayında Türkiye'de Marmara Bölgesi'nin batısı, Ege Bölgesi, Akdeniz Bölgesi’nin Antalya Bölümü ile Silifke yöresi ve Amasya civarı haricinde hemen her yerde nemli ve normal alanlar egemen olmuștur. Nemli alanlar Doğu Anadolu'da Hakkâri Bölümü, Yukarı MuratVan Bölümü, Erzurum- Kars bölümü, Karadeniz Bölgesi'nde Doğu Karadeniz Bölümü ile Nevşehir, Kahramanmaraş, Tokat yöreleri arasında ve İskenderun körfezi ile Kocaeli Yarımadası Platosu civarında meydana gelmiştir (Şekil 7c). Temmuz ayında ise nemli ve normal alanlar çok daha fazla egemen olmuştur. Yıldız Dağları, Biga Yarımadası, Ege Bölgesinde Ege Bölümü ve Tokat yöresi civarı haricinde hemen her yerde normal ve nemli koşullar gözlenmiştir (Şekil 7d).

\subsection{3 ve 1994 y1lı kuraklık desenleri}

Türkiye'de 1993 yılının şubat ayında Trakya'dan başlayarak Biga yarımadasına oradan da Gökova körfezine bir kuşak halinde uzanan alanlar ile Fethiye ile İskenderun körfezi çevresi ve Eğirdir gölü çevresin haricinde hemen hemen her yerde normal ve nemli koşullar egemen olmuştur. Ayrıca, Türkiye'de Doğu Anadolu Bölgesi, Karadeniz Bölgesi'nde Orta ve Doğu Karadeniz ve İç Anadolu'da Orta Kızılırmak Bölümü ile Yukarı Sakarya Bölümü, Doğu Anadolu Bölgesi ve Taşeli yarımadasında aşırı nemli alanların varlığı gözlenmiştir (Şekil 8a).Temmuz ayında ise kurak alanlar beklenirken aksine geniş alanları kapsayan aşırı nemli alanlar ile normal alanların varlığ göze çarpmaktadır. Trakya'nın batısı, Biga yarımadası, Çandarlı ile Güllük körfezi ve Haymana platosu çevresi haricinde hemen her yerde nemli ve normal koşullar gözlenmiştir. Aşırı nemli alanlar Güneydoğu Anadolu Bölgesi, Hakkâri Bölümü, Yukarı Fırat Bölümü, Yukarı Murat-Van Bölümü, İç Anadolu'da Yukarı Kızılırmak Bölümü, Orta Karadeniz ile Doğu Karadeniz'in batısı ve İskenderun ile Antalya körfezi arasındaki alanlar arasında mevcuttur (Şekil 8b). 
a)

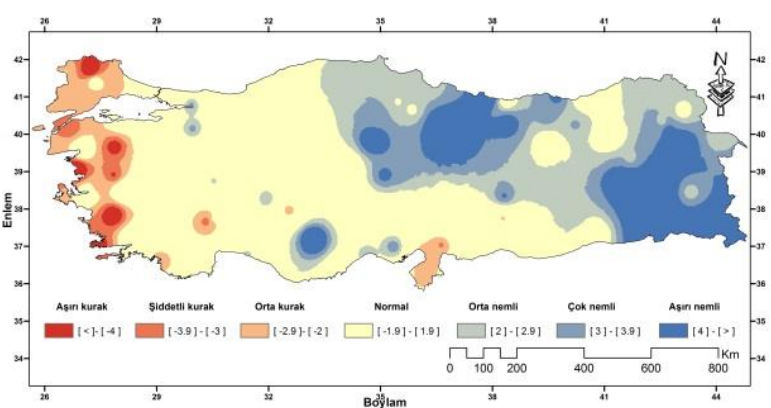

c)

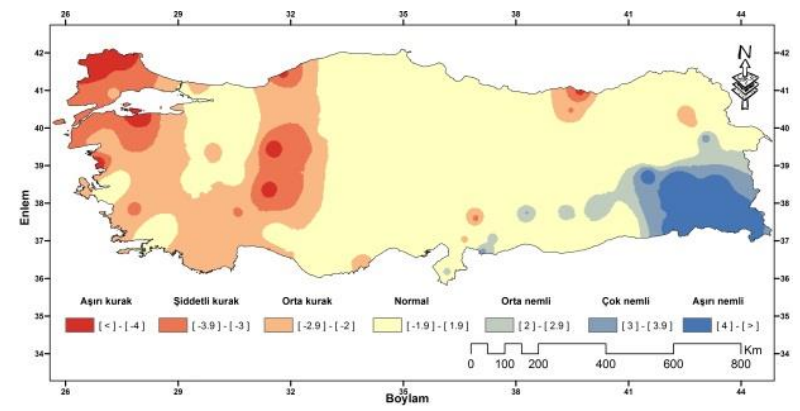

b)

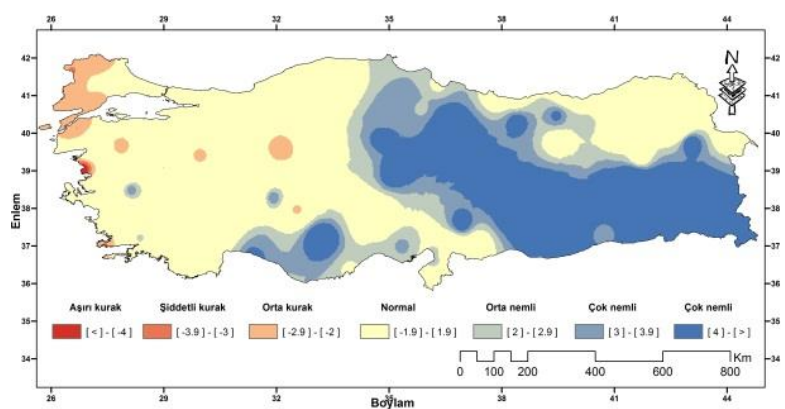

d)

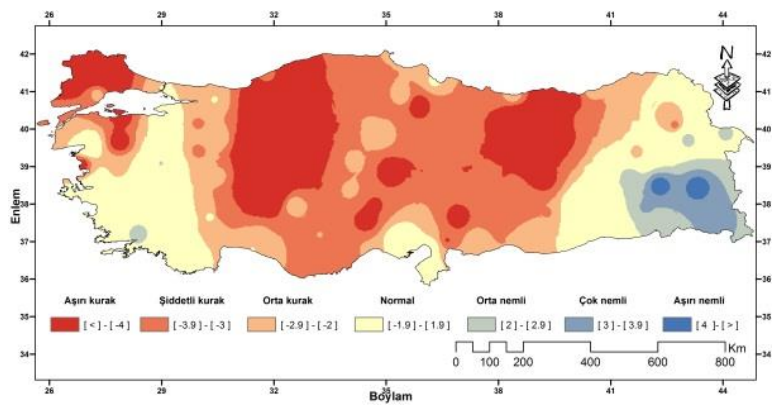

Şekil 8: 1993 ve 1994 yılı şubat ve temmuz ayı Palmer kuraklık şiddeti indisi haritaları: (a) 1993 yılı Şubat ayı PDSI haritası, (b) 1993 yılı Temmuz ayı PDSI Temmuz haritası, (c) 1994 yılı Şubat ayı PDSI haritası, (d) 1994 yılı Temmuz ayı PDSI haritasi.

1994 Şubatının kuraklık indisi dağılış haritasında Türkiye'de Marmara Bölgesi, Ege Bölgesi, İç Anadolu'nun Yukarı Sakarya Bölümü ile Konya Bölümü, Batı Karadeniz'in batısı ile Trabzon ve çevresinde gözlemlenir. Bu alanlar haricinde ise normal ve alanlar egemen olmuştur. Aşırı nemli alanlar ise Hakkâri Bölümü ve çevresinde gözlenmiştir (Şekil 8c). Temmuz ayındaki kuraklıklar ise Türkiye'de daha geniş ve daha şiddetli olmuştur. Kurak alanlar Karadeniz Bölgesi, Marmara Bölgesi, Doğu Anadolu'da Yukarı Fırat Bölümü ile Güneydoğu Anadolu'da Orta Firat Bölümünde görülürken nemli alanlar ise Türkiye'nin Hakkâri bölümü çevresi ile Gökova körfezi çevresine gözlemlenir (Şekil $8 d)$.

\subsection{1 ve 2006 y1l1 kuraklık desenleri}

Türkiye'de 2001 yılının Şubat ayında çok şiddetli kuraklıklar meydana gelmiştir. Klimatolojik olarak nemli olan şubat ayında Türkiye'nin neredeyse bütün bölgelerinde çok şiddetli kuraklık yaşanmıştır. Çok küçük olan nemli alan sadece Rize çevresinde gözlenirken normal koşulların hakim olduğu alanlar ise Güneydoğu Torosların batısı, Sinop ve Rize ile Trabzon çevresinde gözlenir (Şekil 9a). 2001 yılının temmuz ayında şubat ayına benzer bir şekilde Türkiye'nin hemen hemen her bölgesinde kurak koşullar yaşanmakla birlikte kuraklığın şiddeti çok daha yüksektir. Ancak yurdun Güneydoğu Anadolu Bölgesi ise nemli ve normal alanların yaşandığı bölgedir. Ayrıca Fethiye, Antalya körfezi ile Silifke ve Rize yöresi çevresinde nemli alanların varlığı göze çarpar (Şekil 9b).

2006 yılı şubat ayında Palmer kuraklık şiddeti indisine göre genel olarak Akdeniz Bölgesi’nin batı ve orta bölümleri ile İç Anadolu'nun güneydoğusu, Tuz Gölü havzası ve Konya bölümü dışında çoğunlukla normal ve nemli (yağışlı) koşullar egemen olmuştur. Ekstrem nemli koşullar ise özellikle Orta ve Doğu Karadeniz ile Kuzeydoğu Anadolu bölümlerinde egemen olmuştur. Bunların dışında 
yağışların normal düzeyi içinde olduğu alanlar içerisinde bazı yerel nemli alanlar da gözlenir (Şekil 9c). 2006 temmuz ayında şiddetli kurak koşullar Edremit körfezi ve çevresinde, Batı Akdeniz kıyılarında Batı Karadeniz'e uzanan bir kuşak boyunca İç Anadolu'da Tuz Gölü havzası ve Konya ovasını içeren orta ve güneydoğu bölümleri ve Doğu Anadolu'da etkili olmuştur. Çok ve ekstrem nemli koşullar ise yalnız Trakya'nın kuzeyi ile Sinop ve Trabzon çevresinde gözlemlenir (Şekil 9d).

a)

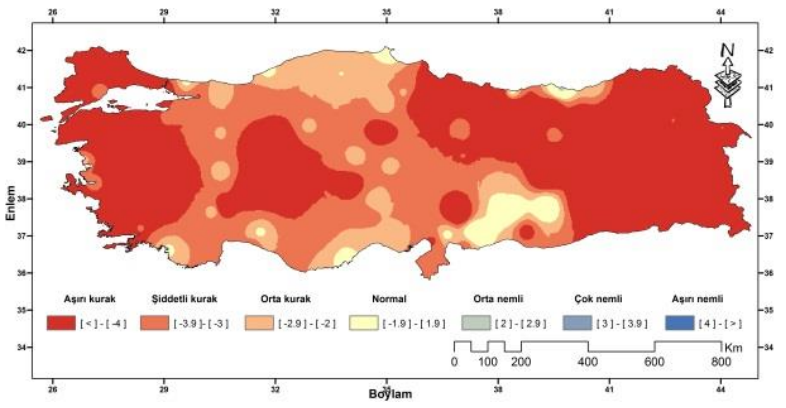

c)

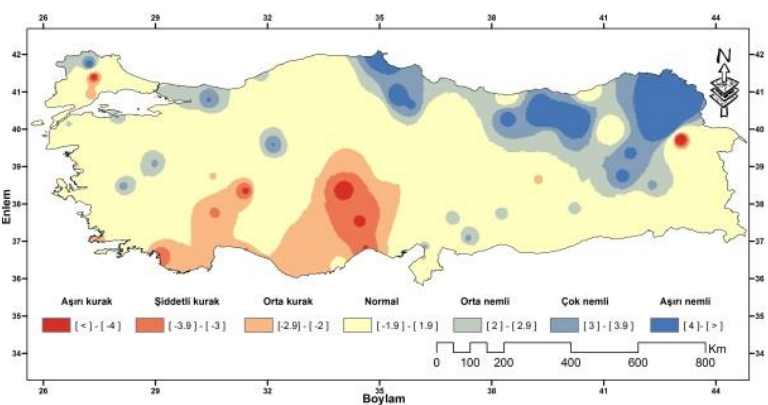

b)

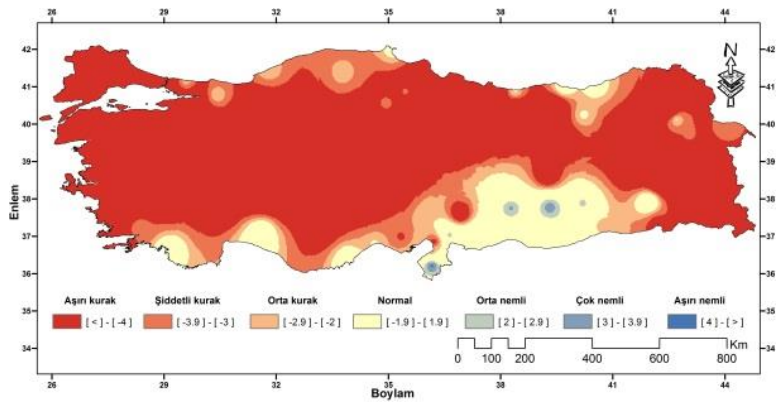

d)

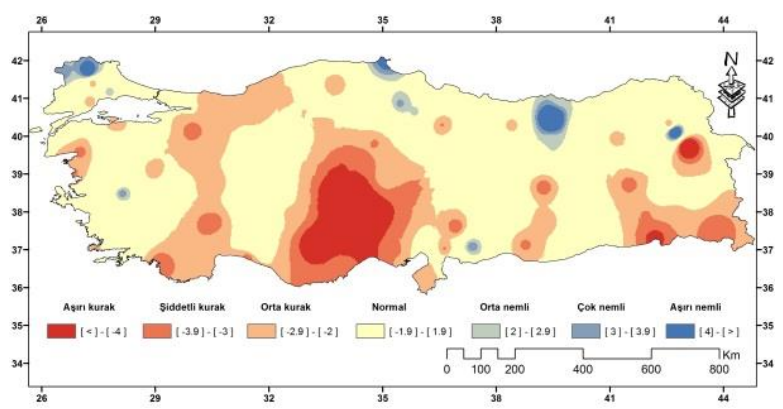

Şekil 9: 2001 ve 2006 yılı şubat ve temmuz ayı Palmer kuraklık şiddeti indisi haritaları: (a) 2001 yılı Şubat ayı PDSI haritası, (b) 2001 yılı Temmuz ayı PDSI Temmuz haritası, (c) 2006 yılı Șubat ayı PDSI haritası, (d) 2006 yılı Temmuz ayı PDSI haritas1.

\subsection{7 ve 2008 yılı kuraklık desenleri}

2007 yılı şubat ayı Palmer kurak şiddeti indisi desenlerine göre Marmara Bölgesi, Ege Bölgesi, İç Anadolu Bölgesi, Karadeniz Bölgesi’nde Orta ve Batı Karadeniz bölümü, Güneydoğu Anadolu Bölgesi ve Taşeli yarımadası çevresinde kurak koşullar görülmekle birlikte Doğu Anadolu'da Van Gölü kuzeyi haricinde Türkiye'de normal ve nemli koşullar egemen olmuştur. Aşırı nemli alanlar ise sadece Zigana Dağları ve Akşehir gölü çevresinde rastlanılır (Şekil 10a). Temmuz ayında ise kış mevsimindeki kurak alanlar daha da genişlemiş ve Doğu Anadolu Bölgesi haricinde neredeyse tüm Türkiye'de etkili olan kurak koșullar görülmüștür (Șekil 10b).

Türkiye'de 2008 şubat ayında Türkiye'nin batı ve güney yarısını kaplayan; Batı Karadeniz, Marmara geçiş, Akdeniz, Akdeniz geçiş, Karasal İç Anadolu ve Karasal Akdeniz yağış rejim bölgelerinde şiddetli ve ekstrem kuraklıklar etkili olmuştur. Türkiye'nin geri kalan bölgelerinde ise normal ve çok daha dar olmak üzere nemli koşullar görülür (Şekil 10c). 2008 temmuz ayında Türkiye'de şubat ayından daha şiddetli olmak üzere şiddetli ve ekstrem kuraklıkların yaşandığı bir ay olarak belirmiştir. Bu da 2008 yılının ilk yedi ayında etkili olan kurak koşulların yaz mevsiminde de yansıdığını ve yaz kuraklıklarını şiddetlendirdiğini gösterir (Şekil 10d). 
a)

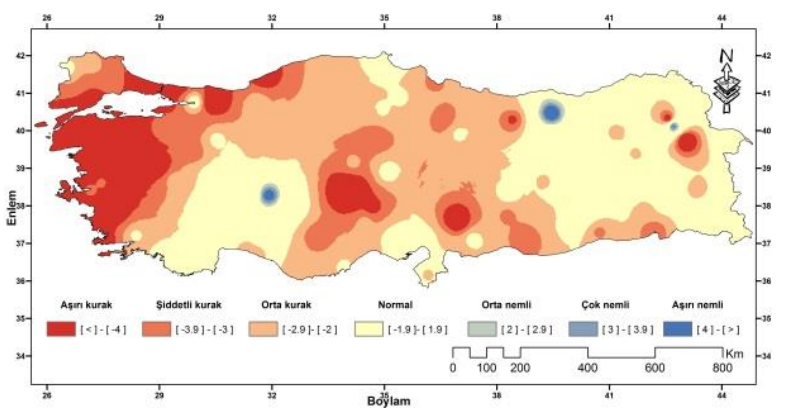

c)

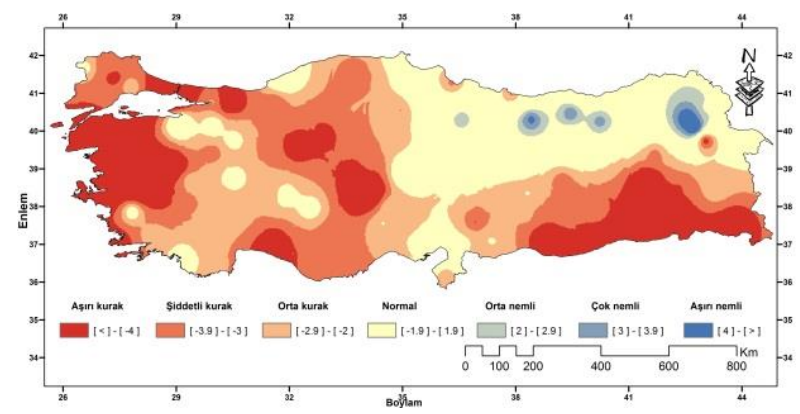

b)

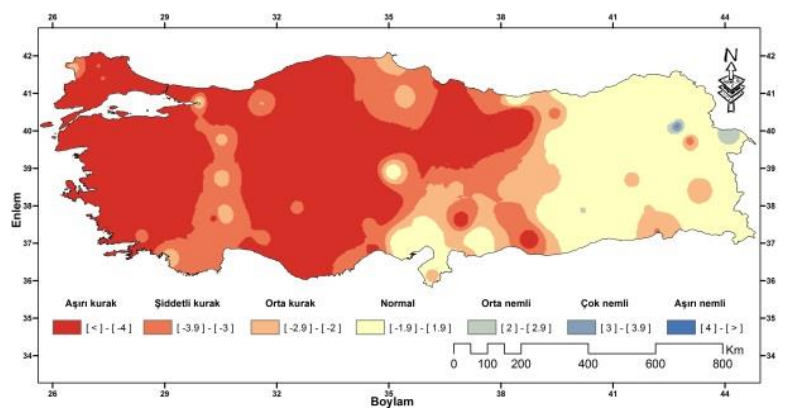

d)

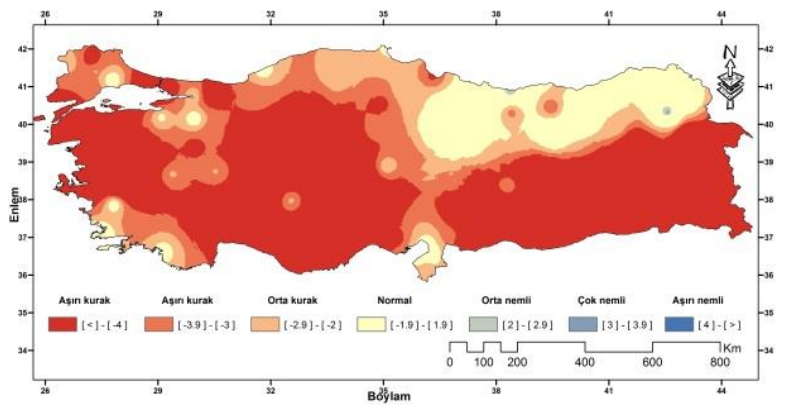

Şekil 10: 2007 ve 2008 y1lı şubat ve temmuz ayı Palmer kuraklık şiddeti indisi haritaları: (a) 2007 y1lı Şubat ayı PDSI haritası, (b) 2007 yılı Temmuz ayı PDSI Temmuz haritası, (c) 2008 yılı Şubat ayı PDSI haritası, (d) 2008 yılı Temmuz ayı PDSI haritasi.

\section{Sonuçlar}

Çalışmanın sonuçlarına genel olarak bakıldığında, yağış klimatolojisi açısından kurak dönem olan temmuz ayında kurak bir dönem beklenmesine rağmen, 1972 yılında sırasıyla Güneydoğu Anadolu bölgesinin tümü, Doğu Anadolu, Batı Karadeniz ve Çatalca-Kocaeli bölümlerinde nemli geçtiği görülür. Benzer biçimde 1983 yılında Güneydoğu Anadolu bölgesi ve Batı Karadeniz bölümü; 1984 y1lında Ege bölgesi ile Batı Karadeniz; 1991 yılında Marmara bölgesi İzmir körfezinden kıyı boyunca devam ederek Batı Karadeniz Bölgesinin sonuna kadar bir şerit halindeki yerlerde; 1992 y1lında Doğu ve Güneydoğu Anadolu, İç Anadolu, Akdeniz, Karadeniz bölgeleri ile Çatalca-Kocaeli Bölümü; 1993 yılında ise Doğu Anadolu Bölgesi ile Orta-Batı Karadeniz Bölümünde aşırı nemli geniş alanların varlığı görülmektedir.

Ayrıca Şubat ayı, yani Türkiye ve Akdeniz havzasında nemli dönem olarak geçen bu ayda ise, Türkiye'de alansal olarak sırasıyla; 1971 yılında Doğu, Güneydoğu, İç Anadolu bölgeleri ile Orta-Batı Karadeniz Bölümü; 1973 yılında Akdeniz, İç Anadolu Bölgeleri ve Yukarı Fırat, Orta-Batı Karadeniz ile Ege Bölümü; 1974 yılında Akdeniz, Güneydoğu, Doğu, İç Anadolu bölgeleri ve Orta-Batı Karadeniz ile Ergene-Güney Marmara Bölümü; 1989 yılında Ege ile Güneydoğu Anadolu Bölgeleri; 1990 yılında Yıldız Dağlarından Antalya körfezine kadar şerit halindeki alanlar ve Güneydoğu Anadolu Bölgesi; 1991 yılında Yıldız dağlarından başlayıp Ege ve Akdeniz kıyılarına oradan Güneydoğu ve Doğu Anadolu bölgesinin güneyine bir kuşak halindeki alanlar; 2001 yılında tüm Türkiye; 2007 yılında Doğu Anadolu Bölgesi, Antalya Bölümü ile Batı Karadeniz Bölümü hariç tüm Türkiye; 2008 yılında Doğu Anadolu Bölgesi ile Orta- Batı Karadeniz Bölümü hariç tüm Türkiye’de orta-şiddetli-aşırı kurak alanların varlığı gözlemlenmiştir. 
Kurak geçen yılların hem nemli hem de kurak döneminin alansal dağılımına bakıldığında, yağış klimatolojisi açısından Türkiye'nin en yağışlı bölgesi olan Karadeniz bölgesi kuraklığın en hafif şiddetle yaşandığı bir bölgedir. Diğer bir şekilde gerek kurak ve gerekse nemli dönemde kurak koşullarım en fazla hissedildiği bölge Marmara bölgesi olmakla birlikte, bu koşullar özellikle bölgenin Trakya yöresi ile Biga yarımadası çevresinde yoğunlaşmıştır. Genel olarak bakıldığında ise seçilen yıllar içerisinde, aşırı şiddetli kuraklığın yaşandığı yerlerin, ülkenin hemen her bölgesine dağıldığı görülür. Ancak, aşırı kuraklıkların sıklıkları göz önüne alınırsa; Marmara, Akdeniz, Güneydoğu Anadolu, Doğu Anadolu, İç Anadolu, Ege ve Karadeniz bölgeleri şeklinde şiddet derecesine göre siralanabilir.

Türkiye'deki kurak yılların veya dönemlerin (özellikle kış dönemleri) gerçekleşmesinde, atmosferdeki uzak bağlantıların (teleconnection) ve desenlerin etkisi de vardır denebilir. Örneğin Türkeş ve Erlat (2003 ve 2005)'e göre Türkiye'de meydana gelen kurak yılların büyük bir kısmı NAO indisinin pozitif dönemine denk düşmektedir.

$\mathrm{Bu}$ çalışmada çıkan sonuçların yanı sıra, iklim benzeşim (simülasyon) modelleri çıktıları kullanılarak, kuraklığın geçmiş klimatolojisinin özelliklerinin incelenmesinin dışında gelecekte de var olacak kuraklaşma eğiliminin klimatolojik açıdan değerlendirmesinde kullanılabilir. $\mathrm{Bu}$ şekilde, özellikle tarım, hayvancılık ve toprağa bağlı sanayi üretim ve çevre açısından yöneticilere bilimsel bir destek sunacağı için benzeşim modellerinin kuraklık yönetiminde faydalı bir araç olarak kullanılması gerekir.

Çalışmanın sonuçları incelendiğinde daha önceki bilimsel çalışmalardan elde edilen sonuçlar ile bir paralellik sergilediği görülmüştür. Bu sonuçla, Palmer Kuraklık Şiddeti İndisinin Türkiye’de kuraklığın izlenmesi ve kuraklık yönetiminde yararlı bir araç olarak kullanılabileceği önerilebilir.

Teşekkür: Bu çalışma Abdullah Akbaş'ın “Türkiye'de Palmer Kuraklık İndisine Göre Kuraklığın Alansal ve Zamansal Değişiminin İncelenmesi” adlı yüksek lisans çalışmasının bir kısmından ortaya çıkmıştır. Çalışmanın her aşamasında yorumlarını ve katkılarını esirgemeyen çok kıymetli hocam Prof. Dr. Murat Türkeş'e çok teşekkür ederim.

\section{Referanslar}

Alley, W.M. (1984) "The Palmer Drought Severity Index: Limitations and assumptions", Journal of Climate and Applied Meteorology, 23:1100-1109.

Byun, H.R.; Wilhite D. A. (1999) "Objective quantification of drought severity and duration”, Journal Climate, 12, 27472756.

Palmer, W. C. (1965) Meteorological Drought, Weather Bureau Research Paper No. 45, U.S. Department of Commerce, Washington, D.C.

National Drought Mitigation Center (NDMC) : Drought Basics, Planning (http://drought.unl.edu, 15.11.2012)

Tatlı, H. and Türkeş, M. (2011) "Empirical orthogonal function analysis of the Palmer drought indices", Agricultural and Forest Meteorology, 151: 981-991.

Thornthwaite, C. W. (1948) An Approach toward a rational classification of climatell, Geography Review, 38, 55-94.

Türkeş, M. (1990) Türkiye'de Kurak Bölgeler ve Önemli Kurak Yıllar, Basılmamış Doktora Tezi, İstanbul Üniversitesi Deniz Bilimleri ve Coğrafya Enstitüsü, İstanbul.

Türkeş, M. (1996) "Spatial and temporal analysis of annual rainfall variations in Turkey", International Journal of Climatology, 16, 1057-1076.

Türkeş, M. (1998) "Influence of geopotential heights, cyclone frequency and southern oscillation on rainfall variations in Turkey", International Journal of Climatology, 18, 649-680.

Türkeş M. (2010) Klimatoloji ve Meteoroloji (Climatology and Meteorology).Birinci Baskı, Kriter Yayınevi - Yayın No. 63, Fiziki Coğrafya Serisi No. 1, ISBN: 978-605-5863-39-6, 650 + XXII sayfa, İstanbul

Türkeş, M. (2011) “Akhisar ve Manisa Yörelerinin Yağış ve Kuraklık İndisi Dizilerindeki Değişimlerin Hidroklimatolojik ve Zaman Dizisi Çözümlemesi ve Sonuçların Çölleşme Açısından Coğrafi Bireşimi”, Coğrafi Bilimler Dergisi, 9, 7999.

Türkeş, M.; Erlat, E. (2003) "Precipitation changes and variability in Turkey linked to the North Atlantic Oscillation during the period 1930-2000", International Journal of Climatology, 23, 1771-1796. 
Türkeş, M.; Erlat, E. (2005) "Climatological responses of winter precipitation in Turkey to variability of the North Atlantic oscillation during the period 1930-200\|, Theoretical and Applied Climatology, 81, 45-69.

Türkeş, M. and Sümer, U. M. (2004) "Spatial and temporal patterns of trends and variability in diurnal temperature ranges of Turkey”, Theoretical and Applied Climatology, 77: 195-227.

Türkeş, M. ve Tatlı, H. (2010). Kuraklık ve Yağış Etkinliği indislerinin Çölleşmenin Belirlenmesi, Nitelenmesi ve izlenmesindeki Rolü içinde: Çölleşme ile Mücadele Sempozyumu Bildiriler Kitabı, 245-263, Çorum

Türkeş, M., Sümer, U. M. and Demir, İ. (2002). "Re-evaluation of trends and changes in mean, maximum and minimum temperatures of Turkey for the period 1929-1999”, International Journal of Climatology, 22: 947-977.

Türkeş, M., Akgündüz, A. S., Demirörs, Z. (2009) "Palmer Kuraklık İndisi'ne göre İç Anadolu Bölgesi’nin Konya Bölümü'ndeki kurak dönemler ve kuraklık şiddeti”, Coğrafi Bilimler Dergisi 7: 129-144.

Wilhite, D. A. (1996) "A methodology for drought preparedness", Natural Hazards 13:229-252

Wilhite DA (2007) Preparedness and Coping Strategies for Agricultural Drought Risk Management: Recent Progress and Trends. In: Sivakumar MVK, Motha R (Eds.) Managing Weather and Climate Risks in Agriculture. Springer, Berlin Heidelberg, pp. 21-38

Wilhite, D.A., Buchanan Smith, M. (2005) Drought as Hazard: Understanding the Natural and Social Context. In: Wilhite, D. A. (Ed.), Proceeding of Drought and Water Crises: Science, Technology, and Management Issues. CRC Press, Boca Raton, FL, pp.3-29.

Webb, R.W., Rosenzweig, C.E., Levine, E.R., (2000) Global Soil Texture and Derived Water-Holding Capacities, Data set. Available on-line [http://www.daac.ornl.gov] from Oak Ridge National Laboratory Distributed Active Archive Center, Oak Ridge, Tennessee, U.S.A. doi:10.3334/ORNLDAAC/548. 
